\title{
Hormonal regulation of human adipocytes at the cross-roads between obesity and hypertension Valérie Tikhonoff ${ }^{\mathrm{a}, \mathrm{b}}$ and Jan A. Staessen ${ }^{\mathrm{b}}$
}

Journal of Hypertension 2002, 20:839-841

aD Dipartimento di Medicina Clinica e Sperimentale, Università degli Studi di Padova, Padova, Italy and b ${ }^{b}$ Studiecoördinatiecentrum, Hypertensie en

Cardiovasculaire Revalidatie Eenheid, Departement voor Moleculair and

Cardiovasculair Onderzoek, Katholieke Universiteit Leuven, Leuven, Belgium.

Correspondence and requests for reprints to Dr Jan A. Staessen, Laboratory of Hypertension, Campus Gasthuisberg, Herestraat 49, B-3000, Leuven, Belgium Tel: +32 1634 7104; fax: +32 16347106 ;

e-mail: jan.staessen@med.kuleuven.ac.be
In this issue of the journal, Gorzelniak et al. [1] examined the expression of the genes coding for the components of the renin-angiotensin system (RAS) in the subcutaneous abdominal adipocytes of 30 women, of whom 18 were obese and 10 had hypertension in combination with obesity. Compared with 12 lean women, the expression of the angiotensinogen (AGT) gene was significantly lower in the adipocytes from the 18 obese subjects. Furthermore, the renin, angiotensin II-converting enzyme and angiotensin II type-1 receptor (ATR1) genes were up-regulated in the adipocytes of 10 obese hypertensive women. Thus, Gorzelniak et al. [1] demonstrated that the RAS genes are differently expressed in adipocytes of obese and hypertensive women. Using an innovative approach, these investigators completed their clinical study with in-vitro experiments. They observed that hydrocortisone increased ATR1 gene expression in human adipocytes in a timeand dose-dependent manner, whereas hydrocortisone did not influence the expression of the other RAS genes. Furthermore, insulin, $17 \beta$-oestradiol, triiodo-Lthyronine and angiotensin II did not influence any of the RAS genes in the in-vitro experiments. The work of Gorzelniak et al. [1] is an important contribution to the existing literature, but should also be interpreted within the context of certain limitations. Although the sample size was larger than in many other reports, the Berlin group only recruited women. Furthermore, differences in age and menstrual cycle may have impacted on the findings and the study did not include lean hypertensive women.

The RAS has long been recognized as an important regulator of systemic blood pressure, renal electrolyte homeostasis, brain function and vascular growth. Components of the RAS are present in a variety of tissues, such as the kidney, adrenal gland, brain, heart and arterial wall [2-4]. Over the past decade, evidence has accumulated demonstrating that in many organs this locally expressed RAS behaves as an autocrine and/or paracrine regulatory system $[5,6]$. More recently, in line with the findings of Gorzelniak et al. [1], several authors reported that some RAS components are locally produced in adipose tissue [7-10]. These findings gave rise to the hypothesis that the intra-adipocyte RAS system might play an important pathogenetic role in the development of human obesity and associated chronic disorders, such as hypertension. However, the functional significance of the local RAS in adipocytes remains to be clarified.

Angiotensin II, produced by conversion of AGT by the local RAS of adipocytes, participates in the control of the growth and differentiation of fat tissue [11] and in the regulation of adipogenesis and lipid metabolism [12]. Recently, Van Harmelen et al. [13] demonstrated that, in subcutaneous adipose tissue from obese men, AGT mRNA expression was twice as high as in nonobese controls. In addition, these authors found a positive correlation between body mass index and local AGT mRNA expression in subcutaneous adipose tissue. They suggested that, in men, AGT locally produced by adipocytes might contribute to the development of upper body obesity. Gorzelniak et al. [1] reported a lower AGT expression in subcutaneous adipocytes of obese women. Initially, the respective findings of Van Harmelen et al. and Gorzelniak et al. may appear to be contradictory. However, in young and middle-aged subjects, there exists pronounced sexual dimorphism in body fat distribution, with predominantly central fat accumulation in men and more peripheral fat deposition in women. The amount of visceral fat augments with age in both genders and this increase is present in lean, overweight and obese subjects [14]. Furthermore, after menopause, there is a redistribution of fat tissue from peripheral and abdom- 
inal subcutaneous depots to abdominal visceral sites with a shift from the gynoid towards the android phenotype $[14,15]$. Several investigators found, in lean as well as obese subjects, that AGT mRNA expression is $30 \%$ [16] to $100 \%$ [17] higher in omental than subcutaneous fat tissue. The obese women in the study by Gorzelniak et al. were predominantly $(72.2 \%)$ postmenopausal, and subcutaneous rather than omental tissue was investigated in the clinical part of the study. For the in-vitro experiments, Gorzelniak et al. used fat tissue removed from women undergoing breast reduction surgery. Thus, the site of fat tissue sampling might possibly explain the divergent or apparently contradictory results. In future experiments, the tissue from which adipocytes are harvested should be better standardized according to sex, menopausal status and age, and defined a priori in function of the specific hypothesis to be tested. In contrast to the findings of Gorzelniak et al., Giacchetti et al. [17] found lower AGT mRNA expression in the subcutaneous fat tissue of obese subjects if they were hypertensive rather than normotensive. However, these authors did not specify the gender and age of their participants, which makes interpretation of their results difficult.

In the study by Gorzelniak et al. [1], the plasma concentration of AGT was similar irrespective of blood pressure and body weight. Nonetheless, AGT and variation in its gene have been implicated in the pathogenesis of hypertension and obesity. Jeunemaitre et al. [18] were among the first to show that the $T$-allele of the AGT M235T polymorphism was significantly associated with increased circulating AGT and hypertension. The M235T polymorphism is in linkage disequilibrium with a threonine-to-methionine substitution at amino acid $174(T 174 M)$ [19] and with the two other polymorphisms in the core promoter area of the gene (G-6A and A-20C) [19,20]. Recent research revealed that the $-6 A$ variant is associated with elevated AGT gene transcription, increased AGT gene expression, elevated plasma AGT levels and hypertension [21-23]. The $-20 C$ allele is also correlated with enhanced AGT transcription in vitro [24] as well as higher plasma AGT and increased blood pressure in humans $[19,20]$. Furthermore, several studies noticed an association between obesity-related phenotypes and various polymorphisms in the AGT gene. Ishigami et al. [25] reported a positive correlation between the $-20 C$ mutation, plasma AGT levels and percentage body fat. Rankinen et al. [26] demonstrated that the M235T polymorphism is associated with body fatness in women. Hegele et al. [27] found that, in men, the AGT $174 \mathrm{M}$ allele was associated with a significantly higher systolic blood pressure but a lower waist-to-hip ratio. As blood pressure and obesity are interdependent phenotypes, the role of AGT and polymorphism in its gene must be further clarified. An important issue to be addressed is whether genetic polymorphisms in the AGT gene not only influence circulating AGT levels, but also those in adipocytes or other cells.

In line with previous animal studies [28], Gorzelniak et al. [1] observed enhanced ATR1 mRNA expression in the adipocytes of obese hypertensive women. Furthermore, their in-vitro experiments showed that ATR1 expression increased after incubation with hydrocortisone. Various hormones, including circulating oestrogens, triiodo-L-thyronine and angiotensin II, promote AGT synthesis in human hepatocytes [29]. To date, few studies in humans addressed the issue of the local regulation of the intra-adipocyte RAS [30]. In experimental animals, only glucocorticoids and insulin were shown to be the hormones that in some, but not all, studies modulated AGT expression in adipocytes $[31,32]$.

As expected, the authors found that obesity is associated with higher serum concentration of leptin. This hormone, secreted by fat cells in proportion to body fat stores, is involved in energy balance regulation by inhibiting lipogenesis, stimulating lipolysis and acting on the brain to inhibit feeding [33]. With regard to blood pressure homeostasis, leptin appears to have divergent effects. A pressor response is attributable to sympathetic activation and a depressor action to nitric oxide release and an increase in the renal sodium and water excretion [34]. Although leptin possesses both depressor and pressor actions, its chronic effects appear to be predominantly pressor. The relationship between excess adiposity and blood pressure has long been recognized. In epidemiological studies in the developed world [35], as well as in developing countries [36], body mass index explains up to one-third of the overall blood pressure variability. Leptin may be involved, but certainly other nervous, humoral and/or genetic mechanisms may be key factors in causing the association between hypertension and obesity, or in enhancing the susceptibility of human subjects to become both hypertensive and obese.

The demonstration of a functional RAS within adipocytes and the role of leptin should change our way of thinking about adipose tissue. It should no longer be regarded as a passive depot for storing excess energy in the form of triglycerides, but as a true endocrine organ, which actively regulates pathways responsible for energy balance and fat metabolism. Adipocytes also participate in vascular function and blood pressure control through the secretion of chemical messengers, where activity is controlled by a complex network of hormonal and neuronal signals [6,37].

In conclusion, the role of the local RAS system in adipocytes in the pathogenesis of obesity and chronic 
diseases, such as hypertension and diabetes mellitus, remains to be clarified in men as well as in women. The innovative approach of Gorzelniak et al., combining a clinical study with in-vitro experiments, merits to serve as a model for further research. Future studies should account for possible differences attributable to gender, menopausal status, age, underlying diseases and genetic polymorphisms.

\section{References}

1 Gorzelniak K, Engeli S, Jurgen J, Luft FC, Sharma AM. Hormonal regulation of the human adipose-tissue renin-angiotensin system: relationship to obesity and hypertension. J Hypertens 2002; 20:965-973.

2 Phillips MI, Speakman EA, Kimura B. Levels of angiotensin and molecular biology of the tissue renin-angiotensin systems. Regul Pept 1993; 43: $1-20$.

3 Unger T, Gohlke P. Tissue renin-angiotensin systems in the heart and vasculature: possible involvement in the cardiovascular actions of converting enzyme inhibitors Am Heart J 1990; 65:31-101.

4 Dzau VJ. Circulating versus local RAS in cardiovascular homeostasis Circulation 1988; 77 (suppl I):4-13.

5 Dzau VJ. Implications of local angiotensin production in cardiovascular physiology and pharmacology. Am J Cardiol 1987; 59:59A-65A.

6 Ailhaud G. Adipose tissue as an endocrine organ. Int J Obesity 2000; 24 (suppl 2):S1-S3.

7 Schling P, Mallow H, Trindl A, Löffler G. Evidence for a local reninangiotensin system in primary cultured human preadipocytes. Int $J$ Obesity 1999; 23:336-341.

8 Jonsson JR, Game PA, Head RJ, Frewin DB. The expression and localization of the angiotensin-converting enzyme mRNA in human adipose tissue. Blood Press 1994; 3:72-75.

9 Jones BH, Standridge MK, Taylor JW, Moustaid N. Angiotensinogen gene expression in adipose tissue: analysis of obese models and hormonal and nutritional control. Am J Physiol 1997; 273:R236-R242.

10 Karlsson C, Lindell K, Ottosson M, Sjöström L, Carlsson B, Carlsson LMS. Human adipose tissue expresses angiotensinogen and enzymes required for its conversion to angiotensin II. J Clin Endocrinol Metab 1998; 83:3925-3929.

11 Morgan L, Pipkin FB, Kalsheker N. Angiotensinogen: molecular biology, biochemistry and physiology. Int J Biochem Cell Biol 1996; 28: $1211-1222$.

12 Jones BH, Standridge MK, Taylor JW, Moustaid N. Angiotensin II increases lipogenesis in 3T3-L1 and human adipose cells. Endocrinology 1997; 138:1512-1519.

13 Van Harmelen V, Ariapart P, Hoffstedt J, Lundkvist I, Bringman S, Arner $P$. Increased adipose angiotensinogen gene expression in human obesity. Obesity Res 2000; 8:337-341.

14 Enzi G, Gasparo M, Biondetti PR, Fiore D, Semisa M, Zurlo F. Subcutaneous and visceral fat distribution according to sex, age and overweight, evaluated by computed tomography. Am J Clin Nutr 1986; 44:739-746

15 Zamboni M, Armellini F, Milani MP, De Marchi M, Todesco T, Robbi R, et al. Body fat distribution in pre- and post-menopausal women: metabolic and anthropometric variables and their inter-relationships. Int J Obes Relat Metab Disord 1992; 16:495-504.

16 Van Harmelen V, Elizalde M, Ariapart P, Bergstedt-Lindqvist S, Reynisdottir S, Hoffstedt J, et al. The association of human adipose angiotensinogen gene expression with abdominal fat distribution in obesity. Int $J$ Obes Relat Metab Disord 2000; 24:673-678.

17 Giacchetti G, Faloia E, Sardu C, Camilloni MA, Mariniello B, Gatti C, et al. Gene expression of angiotensinogen in adipose tissue of obese patients. Int J Obes Relat Metab Disord 2000; 24 (suppl 2): S142-S143.

18 Jeunemaitre X, Soubrier F, Kotelevtsev YV, Lifton RP, Williams CS, Charru A, et al. Molecular basis of human hypertension: role of angiotensinogen. Cell 1992; 71:169-180.

19 Jeunemaitre X, Inoue I, William C, Charru A, Tichet J, Powers M, et al. Haplotypes of angiotensinogen in essential hypertension. Am J Hum Genet 1997; 60:1448-1460.

20 Ishigami T, Umemura S, Tamura K, Hibi K, Nyui N, Kihara M, et al. Essential hypertension and $5^{\prime}$ upstream core promoter region of human angiotensinogen gene. Hypertension 1997; 30:1325-1330.

21 Inoue I, Nakajima T, Williams CS, Quackenbush J, Puryear R, Powers M, et al. A nucleotide substitution in the promoter of human angiotensinogen is associated with essential hypertension and affects basal transcription in vitro. J Clin Invest 1997; 99:1786-1797.

22 Hunt SC, Cook NR, Oberman A, Cutler JA, Hennekens CH, Allender PS, et al. Angiotensinogen genotype, sodium reduction, weight loss, and the prevention of hypertension. Trials of hypertension prevention, phase II. Hypertension 1998; 32:393-401.

23 Morgan T, Craven C, Ward K. Human spiral artery renin-angiotensin system. Hypertension 1998; 32:683-687.

24 Zhao YY, Zhou J, Narayanan CS, Cui Y, Kumar A. Role of C/A polymorphism at -20 on the expression of human angiotensinogen gene. Hypertension 1999; 33:108-115.

25 Ishigami T, Tamura K, Fujita T, Kobayashi I, Hibi K, Kihara M, et al. Angiotensinogen gene polymorphism near transcription start site and blood pressure. Role of a T-to-C transition at intron I. Hypertension 1999; 34:430-434

26 Rankinen T, Gagnon J, Perusse L, Rice T, Leon AS, Skinner JS, et al. Body fat, resting and exercise blood pressure and the angiotensinogen M235T polymorphism: the heritage family study. Obes Res 1999; 7:423-430.

27 Hegele RA, Brunt JH, Connelly PW. Genetic variation on chromosome 1 associated with variation in body fat distribution in men. Circulation 1995; 92:1089-1093.

28 Giacchetti G, Sechi LA, Griffin CA, Don BR, Mantero F, Schambelan M. The tissue renin-angiotensin system in rats with fructose-induced hypertension: overexpression of type 1 angiotensin II receptor in adipose tissue. J Hypertens 2000; 18:695-702.

29 Clauser E, Gaillard I, Wei L, Corvol P. Regulation of the angiotensinogen gene. Am J Hypertens 1989; 2:403-410.

30 Schling P, Loffer G. Effects of angiotensin II on adipose conversion and expression of genes of the renin-angiotensin system in human preadipocytes. Horm Metab Res 2001; 33:189-195.

31 Aubert J, Darimont C, Safonova I, Ailhaud G, Negrel R. Regulation by glucocorticoids of angiotensinogen gene expression and secretion in adipose cells Biochem J 1997; 328:701-706.

32 Aubert J, Safonova I, Negrel R, Ailhaud G. Insulin down-regulates angiotensinogen gene expression and angiotensinogen secretion in cultured adipose cells. Biochem Biophys Res Commun 1998; 250 77-82.

33 Frühbeck G, Jebb SA, Prentice AM. Leptin: physiology and pathophysiology. Clin Physiol 1998; 18:399-419.

34 Mark AL, Correia M, Morgan DA, Shaffer RA, Haynes WG. Obesityinduced hypertension. New concepts from the emerging biology of obesity. Hypertension 1999; 33:537-541.

35 M'Buyamba-Kabangu JR, Fagard R, Lijnen P, Mbuy wa Mbuy R, Staessen $\mathrm{J}$, et al. Blood pressure and urinary cations in urban Bantu of Zaire. Am J Epidemiol 1986; 124:957-968.

36 Staessen J, Bulpitt C, Fagard R, Joossens JV, Lijnen P, Amery A. Four urinary cations and blood pressure: a population study in two Belgian towns. Am J Epidemiol 1983; 117:676-687.

37 Shuldiner AR, Yang R, Gong DW. Resistin, obesity, and insulin resistance - the emerging role of the adipocyte as an endocrine organ $N$ Engl J Med 2001; 345:1345-1346. 